\title{
'Difficult' exhibitions and intimate encounters ${ }^{1}$
}

\author{
Jennifer BonnelI* \\ Ontario Institute for Studies in Education \\ Roger I. Simon** \\ Ontario Institute for Studies in Education
}

\begin{abstract}
Over the last thirty years museums around the world have shown an increased willingness to take on what is often characterized as 'difficult subject matter.' Absent in Anglophone museum studies literature, however, is a sustained discussion on what it is about such exhibitions that render them 'difficult' and, most important, what can be achieved by making painful histories public. This paper sets out to stimulate such discussion, illustrating the relevance of our concerns within the context of a comparative analysis of two recent Swedish exhibitions: The Museum of World Culture's No Name Fever: AIDS in the Age of Globalization; and Kulturen's Surviving: Voicesfrom Ravensbrück. Very divergent in their presentation strategies and in the type of information presented, these exhibitions attempt to position their viewers in relation to violence and suffering of 'others' distant in time, place, or experience. We conclude by discussing the ways in which public history might animate a critical historical consciousness, a way of living with and within history as a never-ending question that constantly probes the adequacy of the ethical character and social arrangements of daily life.
\end{abstract}

Key words: difficult knowledge, museum exhibition, intimacy, public history

\section{Introduction}

As with films, television, radio, newspapers, books, and internet websites, museums function as institutions of social memory with a potential public role in constituting what members of any given society understand as their cultural heritage. Taking on this responsibility, these institutions have frequently offered examples of aesthetic, social, and scientific achievements whose purpose is to inspire and mobilize cohesive societal commitments based on the dynamics of recognition, identification, affirmation, and judgment. However, given the increasingly diverse and conflict-ridden character of contemporary societies, museums have begun to realize that civic life requires more than a notion of heritage defined on such terms. Beyond knowledge acquisition and admiration of what is institutionally preserved and presented as valuable heritage, needed are practices of social memory that conceive of cultural inheritance as a process requiring the commitment to critically engage a past that is both inspiring and despairing. Thus it is no surprise that over the last thirty years, many museums have attempted to move away from a singular emphasis on confirming presentations of patriotism, triumph, and great deeds toward a greater appreciation of the complexities, competing motivations, and potential for aggression inherent in human relationships. In her keynote address to the International Council of Museums' annual conference in 2000, Barbara Kirshenblatt-Gimblett observed that rather than simply celebrating history, a 'new honesty' has encouraged museums to 'open up for public interpretation the darker side of human society' and to do so 'more reflexively and self-critically'(2000: 9). Evident in a proliferation of exhibitions related to conflict, violence, loss, and death is the increasing willingness of museums to take on what is often characterized as 'difficult subject matter'.

While the prevalence of such exhibitions is growing, absent in Anglophone museum studies literature is a sustained discussion on what it is about such exhibitions that renders them 
'difficult' and, most important, what can be achieved by making painful histories public. ${ }^{2}$ This paper is intended to help stimulate such discussion. First we review some commonplace assumptions about the notion of difficulty. We then conceptually consider the ways that difficult exhibitions implicate viewers in coming to terms with histories of violence and suffering. Two central concepts will inform our discussion: first, the notion that 'difficult' exhibitions at times tender a burdensome 'gift' - a demanding bequest that contains within it the expectation of an empathic response; and second, the notion of the intimate encounter, an exhibition experience which offers visitors the potential for insight that may support new ways of relating with and within the world around them. In the final section of the paper we draw on the 'first-hand' experience of one of the authors to provide a conceptual illustration of the diverse ways in which two recent Swedish exhibitions encourage the possibility of intimate encounters, and specifically, the ways in which certain exhibition design features might help to provoke such experiences. The Museum of World Culture's No Name Fever: AIDS in the Age of Globalizationpresents multiple perspectives and fragmentary narratives in documenting the experience of HIVIAIDS in different regions around the world. Emphasis is placed on multimedia forms and on emotion as both an entry to and an organizing feature of the exhibition's content. Kulturen's Surviving: Voices from Ravensbrück, conversely, employs more traditional museological forms-glass display cases and artefact drawers - to present diminutive personal objects created by women survivors of a Nazi concentration camp. Very divergent in their presentation strategies and in the type of information presented, these exhibitions attempt to position their viewers in relation to violence and suffering of 'others' distant in time, place, or experience. As such they are instances of museological practice that attempt to productively deal with 'the dark side of history.'

Research conducted for this paper forms part of a larger project titled The Legacy of Testament: Case Studies Toward Re-Thinking the Practice of Public History. In June 2005, project staff Jennifer Bonnell and Darryl Leroux travelled to Sweden to interview museum curators, designers, and programming staff at the Museum of World Culture (MWC) and at Kulturen. Seven interviews were conducted with staff at the MWC, and three with staff at Kulturen. ${ }^{3}$ Supplementing the information drawn from interviews were comments and observations recorded by Bonnell and Leroux during their visits to the exhibitions. The purpose of this field work was to understand the various ways museum staff at these institutions approached the problem of exhibit design in the context of the exhibitions mentioned above. Our intent was not to assess and evaluate the 'success' of these exhibitions from the standpoint of visitorship or audience responses. ${ }^{4}$ Rather our interest was in conceptualizing how different design strategies might be understood as offering diverse kinds of pedagogical encounters when presenting subject matter deemed 'difficult'.

\section{The 'difficult' exhibit}

To begin with, the 'difficult' exhibition needs to be distinguished from one that has been deemed controversial. Much ink has been devoted to the phenomenon of the controversial exhibition, one that provokes serious public disagreements about the adequacy and accuracy of an exhibit's narrative strategies and interpretative frame. In addition to issues of adequacy and accuracy, these disagreements have also focused on the exclusions enacted by an exhibition, the ethics of exhibiting particular objects, or even the legitimacy of holding an exhibition in the first place. Furthermore, given that historical events recounted through the medium of the museum are perceived as receiving community recognition, at times an exhibition might be deemed controversial if, in the difference between what is publicly named and what is not, it seems to unjustly privilege one type of oppression over other types, or the suffering of one group over that of another. Discussions of such exhibition controversies have become a staple of museum studies literature and the institutional legacies of such exhibitions have become legendary. Well known, for example, are the Out of Africa exhibition at the Royal Ontario Museum, Toronto (1989), the Enola Gay exhibition at the Smithsonian's National Air and Space Museum, Washington (1997-98), Sensation at the Brooklyn Museum of Art (1999-2000), and Mirroring Evil: Nazi Imagery/Recent Art at the Jewish Museum, New York (2002). ${ }^{5}$ 
Beyond its potential for controversy, what might be meant by the 'difficult exhibit?' As a first pass in addressing this question we note several commonplace ways of designating difficulty. What these characterizations have in common is a notion of 'difficulty' understood as an aspect of visitor experience that implicates both cognitive and affective aspects of that experience. Thus one way an exhibition might be said to be difficult is if visitors undergo significant challenges to their interpretive abilities. This is a familiar issue for those museums that seek to honour the absence of simple endings in history and the presence of multiple perspectives on historical events. In this regard, open-ended exhibitions have become increasingly common. Unfinished or ambiguous stories, however, can be frustrating or challenging for visitors, each of whom arrives with their own anticipations drawn from their personal lived experience. Such exhibitions may indeed require visitors to engage in the process of confronting and dismantling their expectations and complicating their desire for a particular 'way of telling' the story. This is a process that may be contested or refused with accompanying degrees of anxiety, anger, and disappointment.

Somewhat differently, an exhibition might be judged as difficult if it is experienced as eliciting the burden of 'negative emotions', those unpleasant and troublesome feelings of grief, anger, shame, or horror that histories can produce, particularly if they raise the possibility of complicity of one's country, culture, or family in systemic violence such as the seizure of aboriginal land, the slave trade, or the perpetration of genocide. But whether one feels complicity or not, choosing to submit oneself to the possibility of such emotions is akin to the experience of standing in the video store attempting to decide between renting one of two films to view that evening, often opting to forego the 'heavier', potentially emotionally implicating film, in favour of another that promises fun and fantasy. Feelings of grief, frustration, or guilt evoked by histories of violence and loss are often associated with a sapping of energy, a departure from positive pursuits, and a negation of life rather than affirmation of it. When exhibitions attempt to mitigate these facets of despair by saddling visitors with moral obligations aimed at the improvement of the human condition, one may experience the guilt and shame that one will never be able to do enough or differently, that at root one is not ready or willing to give up one's advantages and priorities to work to ameliorate the suffering of others.

Finally, difficult exhibitions may evoke a heightened anxiety that accompanies feelings of identification with the victims of violence as well as a potential re-traumatization of those who have experienced past violence themselves. A Nazi flag, for example, will elicit responses from those victimized by the regime that are dramatically different in their potency from those who look upon the flag as a historical document and nothing more. Or take an instance of a poem written by someone who has died of AIDS. What might be observed by one person as a moving artifact of human pathos might for another evoke the unresolved fear and grief experienced at the time of learning that one's partner has contracted the disease. Such scenarios may also lead to accusations that a museum is exploiting the pain of others by producing a voyeuristic, sensationalist version of violence, loss, and suffering.

Evident in this discussion is that what might be experienced as difficult subject matter does not rest with particular objects nor the events to which they refer. Rather the experience of difficulty resides in the efforts to make meaning that are constituted in the relationship between a visitor and the material presented in an exhibit, a relationship that is always specifically contextualized. Thus when discussing difficult exhibitions, the obvious questions are: Difficult for whom? When? Where? In what way? The experience of difficulty will vary with factors such as time and place, gender and generation, political orientation or ethnic and/or national background (Silvén and Bjorklünd 2006). However, while these considerations are important to understanding the unpredictable yet potentially significant character of visitor response, they are not particularly helpful in clarifying why and how museums might responsibly present exhibitions that visitors, in multiple ways, find 'difficult'. One may rightly argue that museums need to embrace the complex, conflict-ridden, and tragic spectrum of human history. Exhibitions in this vein convey the message that this unredeemed history must be confronted in ways that support a hopeful future while simultaneously teaching humility in the face of the unpredictability of life (Silvén and Bjorklünd 2006; Wineburg 2001). Behind this argument is the assumption that if museums present exhibitions that tell troubling stories that have been systemically ignored and/or often willfully forgotten, and do so in a way that is emotionally 
engaging and elicits empathy for others, this will enrich the consideration of civic life in our communities and nation. However, for us this level of conversation leaves something to be desired. Needed is a more in-depth discussion of what such exhibitions might claim of visitors' attentiveness and capabilities and how, when and why such demands might be pedagogically productive. More specifically, what might it mean to take in and care for accounts of lives lived on terms very different from one's own? How might exhibitions position viewers to encounter, acknowledge and live with the troubling experiences of others and make insights from such encounters in ways that may alter both thought and action? The challenge is to design exhibitions to support visitors in the recognition that a 'difficult' exhibition implicates the self in the practice of coming to terms with the substance and significance of history.

\section{Difficult knowledge and intimate encounters}

Having something to communicate to viewers, exhibitions are often designed to address visitors by stating propositions, arguing points of view, questioning existing beliefs, and promising the possibility of knowledge and insight. But additionally, an exhibition may at times enact the presentation of various forms of testament, bequeathing to us traces of the experiences of others and demanding that we attend to these and make some significance from them. On such terms, an exhibition may be understood as enacting a bequest, i.e., making a gift that sets forth the difficult work of inheritance. Such gifts are quite different from those that circulate in systems of exchange relations (Mauss 1954). As something bequeathed, often from the dead to the living, there is no possibility of reciprocity, yet incurred is the obligation to receive the gift by deciding if and how one will live with it (Derrida 1994). In some circumstances, this gift may neither be welcomed nor wanted, burdening us as it does with the complex task of coming to terms with the historical specificity of systemic violence and the unbearable suffering of others. A practice whose outcome is not guaranteed in advance, the work of inheriting such a terrible gift is an inescapable consequence of an exhibition that implicates visitors in the necessity of a response (even if that response is ultimately to ignore the bequest) (Simon 2006a).

The act of exhibiting the material brought into the public realm in both the Surviving and the No Name Fever exhibitions may be understood as offering terrible gifts. Both exhibitions not only proffer propositions about relations of power and the experience of subjection, but the museum staff responsible for these exhibitions have inscribed and bequeathed to visitors testamentary traces of the experience of those who have lived and are still living (and struggling) with that subjection. Each exhibition enacts the giving of a gift that carries with it the demand that visitors attend to and assess the significance of what they are being given. As visitors we are bequeathed something of another's life that is beyond our own experience and asked to not only take this in but as well to take care of it, working to assess its import and subsequently to take it into account as we go about living our lives. ${ }^{6}$

Obviously, how such demanding gifts are received determines much of what it might mean 'to take an exhibition into account'. One of the major tasks in taking an exhibition into account is to settle (at least provisionally) on the meaning and significance of the objects, texts and images that one encounters. When there are problems in doing this, the accomplishment of historical insight becomes troubled. In their study of difficult knowledge, Alice Pitt and Deborah Britzman make it clear that what is difficult in representations of the experience of others is not only a matter of what histories are represented but also the prospect of 'encountering the self through the otherness of knowledge' (2003: 755). What Pitt and Britzman are referring to here are those moments when knowledge appears disturbingly strange or inconceivable to the self, bringing oneself up against the limits of what one is willing and capable of understanding. On such terms, what is difficult about historical knowledge is not just that the materials exhibited elicit anger, horror and disgust, and judgments that past actions were shameful and unjust. More to the point, what defines the difficult exhibit is what happens in that moment when one receives the gift that an exhibition enacts, when one comes face to face with the troubling consequences of 'the otherness of knowledge'. What happens in this moment is an experience that mixes partial understanding with confusion and disorientation, the certainty of another's fear and suffering with one's own diffuse anxiety and disquiet. This is an experience produced when one's conceptual frameworks, emotional attachments, and conscious and 
unconscious desires delimit one's ability to grasp and settle the meaning of past events: one's sense of mastery is undone (Pitt and Britzman 2003: 759). ${ }^{7}$ Unsurprisingly, such moments elicit self-protective ego defenses. For example, one may identify with the other to the extent of losing oneself, and, as a result, fail to grasp the implication of one's difference from others. At the other extreme, one may seek to distance oneself from those who have experienced violence by belittling the significance of their experience.

Despite the possible evasions one might consciously or unconsciously enact when faced by historical traces that are not simply self-affirming, the possibility that historical knowledge might be experienced as difficult also provides an opening for an expanded and responsible sense of what it might mean to take an exhibition into account. The key to such learning, we argue, lies in the possibility of an intimate encounter with the demanding gift of histories of violence and suffering. By intimacy, we refer to the quality of a relationship in which one embodies a significant degree of unrestrained exposure to another, an exposure often enacted as openness to the touch of another. Such openness can be felt as vulnerability and appear as responsiveness. Akin to Lévinas's notion of proximity, intimacy occurs when I am summoned into a relation with someone (or thing) capable of transfixing me. In this state of fascination and fixation, the sovereignty of my ego is overturned yet I remain responsible to the one who demands my acknowledgement (Lévinas 1991: 101-2). While what is at issue within a relation of intimacy is most commonly registered in the quality of an erotic relation between lovers, it gestures as well towards a more generalized sensibility. Within this sensibility and in relation to history, one stands not as an observer seeking comprehension of the terms on which another lives; rather, one is open to the density of detail that traces another life in a way that overflows the objectification and thematic categorization of that detail. Just as one may have difficulty expressing the depth of one's love for a life-partner or child, the significance of a person or an object in an intimate relationship cannot be contained conceptually: the cognitive and emotional quality of the relationship exceeds the sayable.

What then might intimacy imply as a relational mode of engaging with an exhibition? As we have suggested, intimacy involves a sense not of 'knowing' the other, but of receptivity to the particulars of her experience and to the troubling emotions that accompany uncertainty. In the relation between the viewer and the experiences of others presented in an exhibition, intimacy suggests an act of acknowledgement-an openness and acceptance of the other as such - that resists attempts to reduce the other's experience to something graspable or containable. In this act of acknowledgement lies the possibility for insight; the possibility of a transformative critique of one's way of understanding the world. It is important not to mistake this position as rejecting the discerning conceptualization and judgment that comprise historical understanding. Acknowledgement, as Gerald Bruns reminds us, 'is not an alternative to knowing but an interpretation of it, even a critique of it' (Cavell, cited in Bruns: 184). Acknowledgement of particularity —of what is not immediately possible to understand with the authority of my frameworks for negotiating the world -initiates a critique of the substance and grounding authority of these frameworks. In exhibitions that bequeath to us the traces of the experiences of others, particularly those who have been subjected to systemic violence and the experience extreme suffering, intimacy may be understood as a sensibility with the capacity to unsettle the self, enabling a possibility of reflexive critique and transformative insight regarding one's relationship to the past and one's complicity with established historical certainties. On such terms, public history becomes not simply a matter of accurately knowing the past and assessing its historiographic significance, but a force of inhabitation-a sense of $d w e l l i n g$ with the past without 'settling' or mastering it (Simon 2006a, 2006b; Bruns 1999: 120).

Yet this still leaves us with the question: what might it mean to live with, to be with traces of the past in ways that convey the specifics of lives that are neither to be fully known nor finally forgotten? This is clearly one way trouble begins: when I am forced beyond knowing and into a non-appropriative relation of acknowledgement. Crucially, we see such trouble as generative. Herein lies the terrible gift-the difficult process of inheritance that brings with it possibilities for insight, and a new foundation for re-thinking the significance of history beyond the idealized responses of empathy, identification, and solidarity. In the discussion that follows, we will consider the ways in which the two Swedish exhibitions previously mentioned encourage the possibility of intimate encounters. Specifically, we will explore the ways in which three design 
features common to both exhibitions might help to provoke such encounters: those features that enhance the particularity of experiences presented; those that enhance focus and absorption in specific objects and texts; and those that provoke a reflexive critique of one's grasp of what the exhibition offers.

\section{Exhibiting difficult histories - No Name Fever: AIDS in the Age of Globalization}

In December 2004, the Museum of World Culture opened its doors to the public, having dramatically reinvented itself from its former identity as the Ethnographic Museum of Gothenburg. Committed to tackling the problematic colonial heritage of its collections, the museum envisioned itself as 'a place for dialogue, where multiple voices can be heard and also controversial topics can be raised - an arena for people to feel at home across borders' (Museum of World Culture 2004). No Name Fever: AIDS in the Age of Globalization was one of five inaugural exhibitions presented at the museum opening in December 2004; it ran for almost eighteen months, closing in June 2006. The topic of AIDS fit well with the museum's mission to emphasize interdependencies and connections across geographic boundaries, and the need for global responses to global problems. Recognizing the exhaustion of interest in the topic of AIDS in Sweden, museum staff consulted extensively with youth target audiences to inform their approach. The result was a youth-centred exhibition that combined personal narratives with art, film, installations, music, photos and promotional material by artists, activists, policymakers and everyday citizens who have worked to fight the silence about HIVIAIDS.

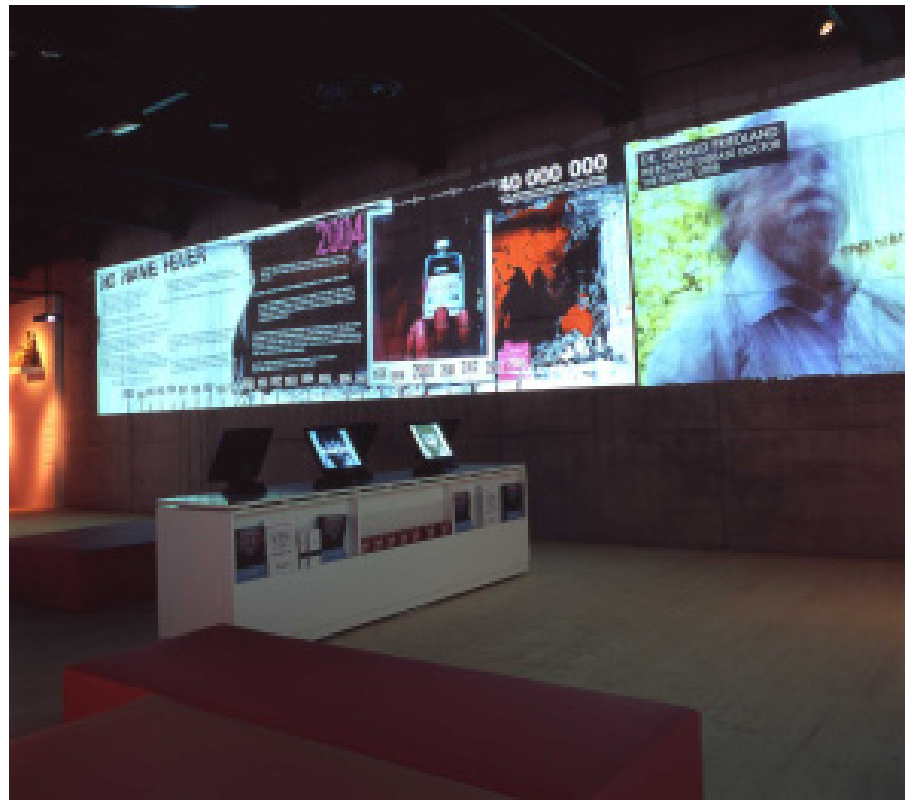

Fig. 1 AIDS Timeline \& video clips, with computer terminals below. Courtesy of the Museum of World Culture, 2005

With an area of more than 1000 square metres, the exhibition consisted of seven circular 'polygons' or display spaces which were each shaped like a cell or molecule, with an opening on one side. The seven polygons were grouped roughly around a central open area, where a large multimedia timeline spanning the back wall scrolled through a series of events and statistics related to the AIDS epidemic from 1981 to the present. To the left of the screen, a bank of touch-screen computers invited visitors to access to additional information (Fig. 1). Between polygons, the white walls provided a screen for the projection of large, shadowy human forms moving through the exhibit - walking, pushing strollers, moving in wheelchairs. These shadows of people on the walls were intended to give visitors a sense of others moving through the exhibition. Then Museum Director Jette Sandahl explained: 'We wanted to create a sense of the collective. You encounter the disease as an individual, but the solution is necessarily collective'.

The seven polygons were arranged to open indirectly onto each other, creating a serpentine-like effect in the visitor's movement from one cell around and into the next. Each 
polygon presented a range of texts, images, and objects thematically organized as different emotional responses to the disease: denial, fear, anger, desire, despair, sorrow, and hope. Conscious of the differences between rich and poor countries in the spread and effect of AIDS, museum staff attempted to find a way of addressing the disease that would resonate with experiences in the North and the South. Emotion was seen as an avenue that cut across the rich and poor divide, providing a point of connection between the variously located human experiences presented in the exhibition, and between these and museum visitors. As Sandahl explained: 'Individuals can relate to another's grief, or sense of hope'. In the interior of each polygon, curved white walls formed a backdrop for still images, video screens, and object display cases. Art, photography, posters, multi-media installations, film and other objects reflected the impact of HIVIAIDS on various continents. While each room in the exhibition contained objects of some kind (for example, a dress made of condoms, a collection of handcrafted dolls made by South African women infected with HIVIAIDS), images and multimedia presentations predominated.

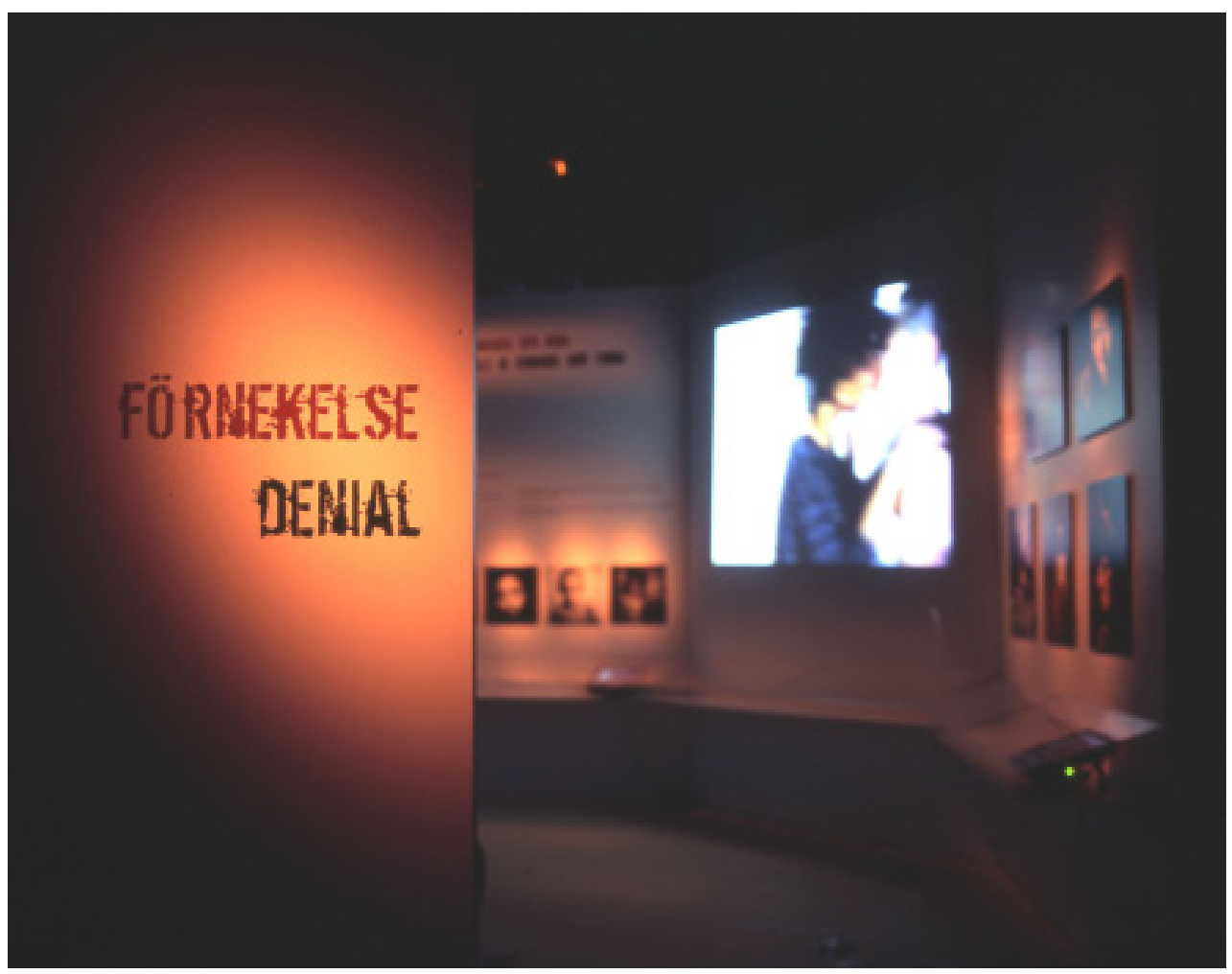

Fig. 2 Entrance to the Denial Polygon. Courtesy of the Museum of World Culture, 2005

A detailed description of the objects, texts and images presented under the theme of 'denial' provides an example of the range and depth of information included in each polygon (Fig. 2). To the left of the entrance to the 'Denial polygon,' a large screen presented 'Kissing Doesn't Kill,' a film produced by Act Up! USA. This video installation dominated the room both aurally and visually. The space also included several video stations equipped with headphones and one or two foot-stools for seating. Available on these screens were a one-minute video installation called 'Forgiveness,' a production of the Gay Group of Bahia, Brazil, which castigated the Catholic Church for its position on AIDS, homosexuality and contraception; and a sixty minute documentary from France called 'Sex, Needles and Roubles', which explored the lives of young 
drug-addicted prostitutes in St. Petersburg and the discrimination they faced among the police force and the medical profession. Adjacent to the video screen near the entrance was a large reproduction of a poster entitled 'AIDSGate: The Truth about Reagan and AIDS' portraying President Reagan in diabolical tones of red and yellow and attacking him for the slowness of his response to the AIDS crisis. Excerpts from three photo-essays took up the remaining wall space: 'The Tandem Spiral', documenting the practice of self-injection of homemade remedies and narcotics in the Ukraine resulting in increases in the spread of HIV; 'AIDS Village', (prohibited in China) documenting the experiences of rural farmers in Henan Province infected with HIV when they sold their blood to illegal collectors; and 'Children of Ceausescu, 19941999,' exploring the lives of Romanian children infected with HIV through public health services during the Ceausescu dictatorship in the 1980s.

The 'Sorrow' polygon created an interesting contrast. Here, the images, texts, and multimedia installations took on a very different tone. Dominating one side of the room was a photo-essay by Gideon Mendel documenting residents' experiences with rising numbers of funerals in South Africa. One image-Mendel's award-winning 'Coffin with Red Ribbons'showed the coffin of fifteen-year-old Khanyisa Eugenia being lowered into her grave. The coffin was littered with red AIDS ribbons. Text from Words from Zarina Geloo of Zambia was stenciled in large text on the wall above the images: 'AIDS has changed the way people live. Now it is changing the way they are buried'. Adjacent to the photo-essay, an excerpt from an interview with a Zambian homecare volunteer provided context:

You know we don't count how many funerals we go to. Today in the cemeteries they are burying them as if it is a competition. Sometimes there can be more than six funerals happening at the same time.... Nearly everyday there is a funeral for someone we know. In Ndola and Kitwe, mourners now have to dig their own graves. Because they have not been paid in four months, the gravediggers are on strike.

A documentary called 'Heavy Traffic' gave visual weight to these words in its portrayal of the immense volume of traffic at Avalon Cemetery in Soweto. In a video station on the opposite side of the room, a short documentary called 'Political Funerals' explored the grief and rage accompanying deaths from AIDS in the American context. The film documented a 1992 funeral procession to the White House led by friends and families of AIDS victims in protest against George Bush Senior's indifference towards the AIDS crisis. Beyond images and death and mourning, objects and texts in this polygon also suggest the theme of remembrance. A section of the 'AIDS quilt', a patchwork of over 44,000 three-by-six foot memorial panels, each commemorating the life of someone who died of AIDS, hung on display on the wall adjacent to the funeral photos.

\section{Exhibiting difficult histories - Surviving: Voices from Ravensbrück}

Founded in Lund in 1892, Kulturen is Sweden's (and the world's) second oldest open air museum. With forty-nine buildings on site, it houses a collection of over two million objects from around the world - the largest collection in Sweden outside of Stockholm. In recent years, the museum adopted a new direction focusing on contemporary issues and challenging subject matter. Exhibitions, according to a 2006 brochure, would 'not flinch from exploring difficult subjects' (Kulturen 2006). Surviving: Voices from Ravensbrück, a permanent exhibition which opened in January 2005, exemplified this new direction. The exhibition focuses on the experience of women prisoners at Ravensbrück, a Nazi concentration camp north of Berlin. The only concentration camp intended primarily for women, Ravensbrück imprisoned over 130,000 women and children from twenty-three different nations between 1939 and 1945. A large number of these women were political prisoners from Poland. Surviving draws upon stories of life in the camp together with an excerpt from the local history of southern Sweden. A brief summary of the provenance of the materials exhibited is useful here.

In the spring of 1945, a convoy of Swedish Red Cross buses traveled to Germany in an effort to repatriate members of the Scandinavian resistance interned within Nazi death camps. In this context, Sweden also accepted as refugees an additional 10,000 survivors from various 
nationalities, including women who had been interned at Ravensbrück. These people were transported to towns in southern Sweden for medical treatment and rehabilitation. When they arrived, Zygmunt Lakocinski, a Polish national and lecturer at Lund University, was enlisted as an interpreter. Lakocinski recognized an opportunity to document evidence of Nazi terror. Together with his colleagues, he recorded about 500 interviews with Polish survivors, over seventy per cent of whom were women from Ravensbrück. ${ }^{8}$ Over the course of these interviews, Lakocinski learned that many women had hidden small objects beneath their clothes, or in the heels of their shoes. The objects ranged widely in function and meaning. They included, for example, a scrap of packaging inscribed with a poem recalled from memory, a tiny cross fashioned of metal bolts, a little doll made of scraps of fabric, a miniature hand-written calendar. Although Swedish officials planned to burn all of the objects the women carried for fear of contamination, Lakocinski managed to save a small number from destruction. Almost sixty years later, in 2004, Lakocinski's three children donated his collection to Kulturen. The following year, Surviving: Voices from Ravensbrück opened. The exhibition presented Lakocinski's entire collection (over 150 objects) supplemented by text drawn from interviews with Ravensbrück survivors that exhibition curator Anita Marcus conducted between 1998 and 2002.

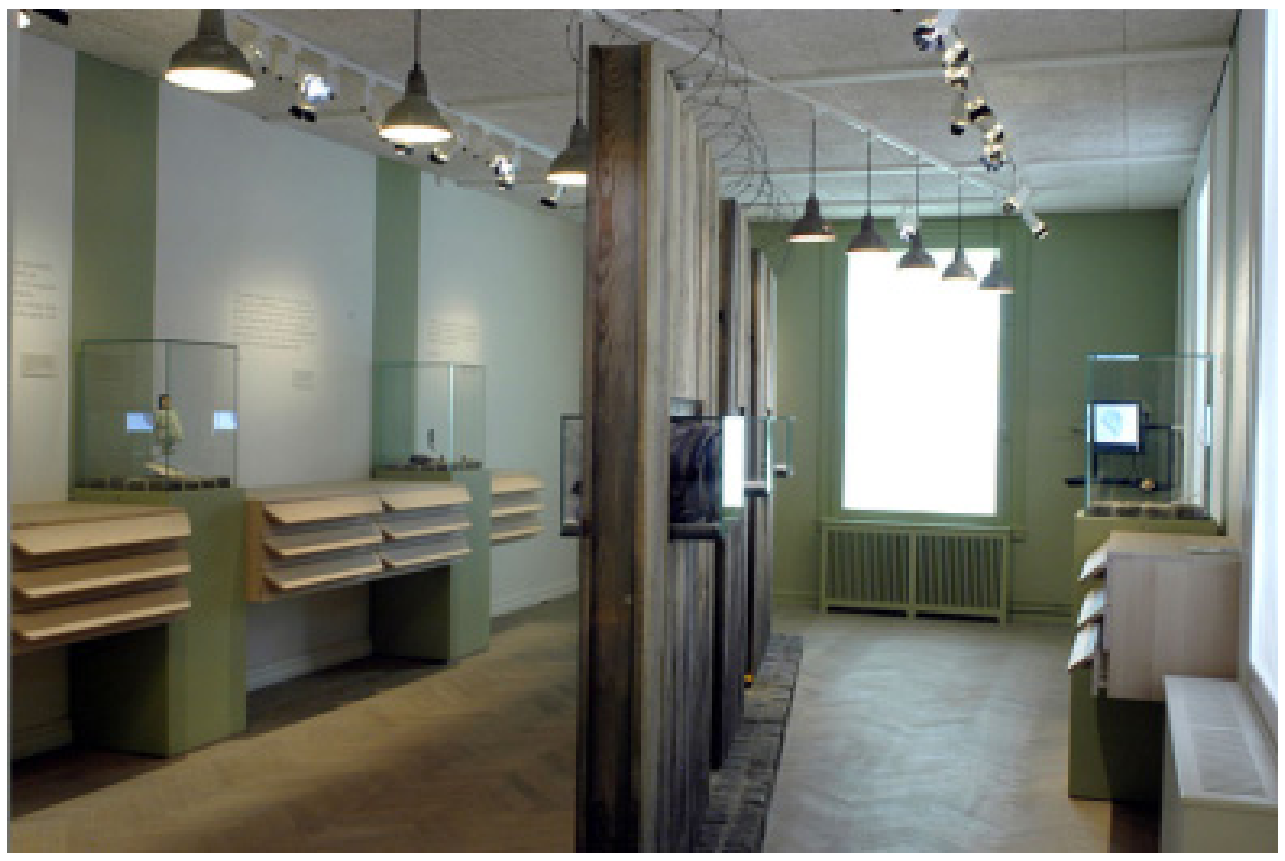

Fig. 3 View of exhibition from entrance. Courtesy of Kulturen, 2005

Unlike No Name Fever, Surviving is an object-centred exhibition; it includes only a few images, and no audio or multimedia elements (Fig. 3). A replica barracks wall, fashioned from rough wood planks and topped with coiled barbed wire, runs diagonally through the centre of the room. Three display cases embedded into the wood panels at intervals present a selection of objects: in the first, a stack of mud-encrusted prison uniforms; in the second, a display of miniature handmade calendars and other treasured objects that women made in the camps; in the third, a pair of slippers, an embroidered kerchief, and a tiny folded piece of paper containing a message to another prisoner. The majority of objects are housed in seven wide chests of drawers that line the walls of the exhibition space. Quotations from women survivors, stenciled on the walls above the artefact chests or printed on card-stock within the artefact drawers, illuminate the significance of the objects in accordance with six exhibition themes: Dehumanization, Sabotage, Useful 
Things, Memorabilia, Religion/Food for the Soul, and Treasures and Gifts. ${ }^{9}$

In the chests of drawers titled 'Sabotage,' objects include satirical drawings of camp life sketched by prisoners on scraps of packaging, and a pair of 'sabotage socks'forced to knit socks for the German army, women prisoners devised a way of making the heels extremely uncomfortable (Fig. 4). A display case next to the Sabotage cabinet presents a hand-made doll accompanied by a quotation explaining how women made dolls for children in the camp, and sometimes used them to smuggle things between barracks. Objects presented in other categories are equally poignant. In the Memorabilia cabinet, a collection of recipes on scraps of paper accompanies a quotation from a woman named Anika: 'In the hut in the evening when it was supposed to be quiet, you could hear 'you take [so] many eggs and [so] much cream...' all the things we didn't have. You thought so much about food that it was a kind of help to get away from the reality'. The Religion/Food for the Soul cabinet presents a collection of miniature hand-made calendars. These are contextualized by a quote from an interview with Apolonia: 'A

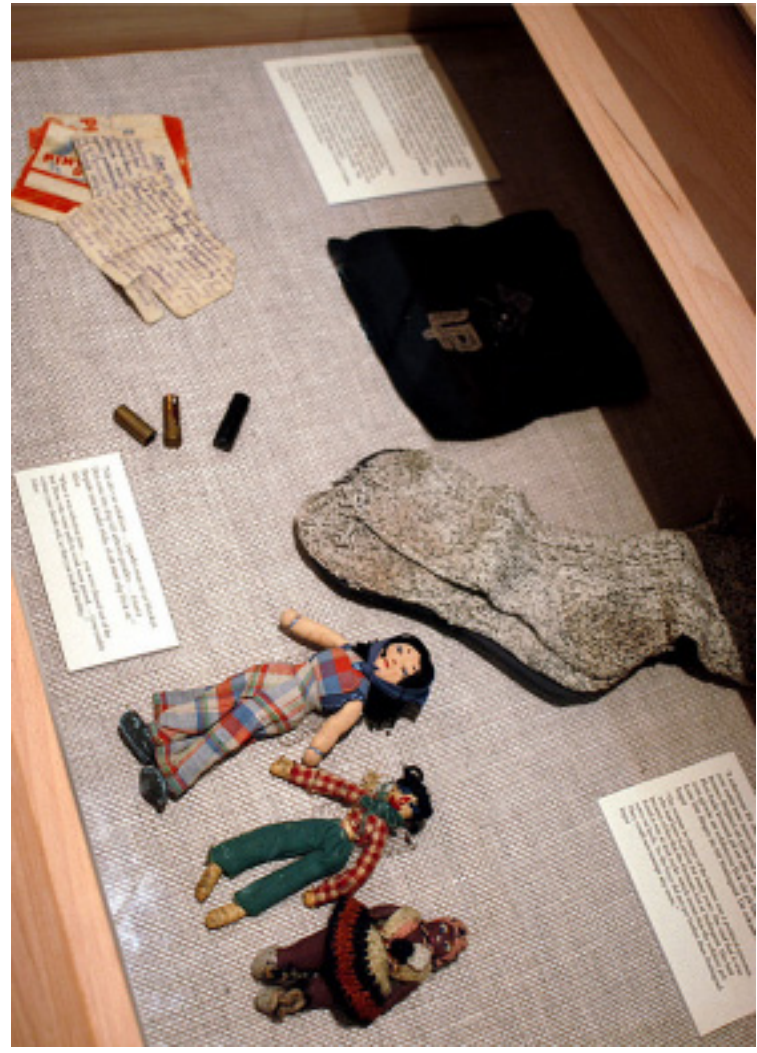

Fig. 4 Artefacts in the 'Sabotage'cabinet. Clockwise from top: writing on bulb cartons, a black fabric handbag, "sabotage socks," dolls for smuggling messages, and lipstick for rouging "life" into one's face. Courtesy of Kulturen, 2005. calendar was worth its weight in gold.... When someone took sick they wanted to check whether that person was in good mental health and they often asked what day it was.... If you weren't able to answer, it could happen that you were sorted out'. While quotations from the curator's interviews with the women survivors form the bulk of the exhibition text, curatorial comments provided additional context in places. For example, next to a small collection of 'memory maps' in the Religion/Food for the Soul cabinet is the statement: 'The Nazis' tactic was to break the prisoners physically and mentally. In the camp there were some older women who tried to counteract this. By trying to remember as many details as possible from their previous lives, it was easier to imagine that there would be a time after the camp'.

\section{Intimacy and exhibitions}

From the prospect of an intimate encounter with a 'difficult' exhibit, what possibilities do the AIDS and Ravensbrück exhibitions offer through their presentation of both gift and demand? The lived experience of AIDS or HIV infection, or the remembered experience of women survivors of Ravensbrück, are worlds apart from the personal experiences of the vast majority of visitors who have come to see these exhibits. Conceived not as spectacles of suffering, but as testamentary encounters with the traces of these experiences, these exhibitions challenge visitors in very different ways to come into a relation of significance with lives lived on terms very different from their own. 
MWC Director Sandahl was quite explicit about this in regard to No Name Fever: 'the material we present is so up close and personal... [that the exhibition] becomes a very personal meeting between... the audience and the person you see on the screen'. Making an exhibition 'up close and personal' was taken quite seriously by the team responsible for No Name Fever. It functioned as a framework for both including and excluding material. As Sandahl admitted:

the Swedish people who were HIVIAIDS infected were not very keen on coming out [in the context of the exhibit].... one person who was interviewed, a very young man... he didn't want to be seen.... He wanted a transcript rather than a voice... [or] he wanted voice warping. At some point we said no, we will not anonymize this further, relative to all the people from all over the world who actually invest their faces and their voices in this.

The 'very personal meeting' aspired to in No Name Fever was explicitly tied to the ambition of inculcating a pedagogically and politically productive relationship between MWC personnel, the experiences represented, and those visiting the exhibition. The intent was beyond simply providing information and awareness of a global health crisis. As Sandahl commented: 'we were very keen that HIVIAIDS should not be an illness that other people have. [It should] not be an illness that people have down in Africa or people have somewhere else'. Instead, exhibition designers sought to stress the economic and political interdependencies and the connections across geographic boundaries. These connections, Sandahl continued, 'breed identification and empathy across some very large gaps [in experience and agency]... you don't want people to necessarily go in there and identify with being HIVIAIDS infected.... You want to be able to just get a little bit of a feeling of what it might be like. So I think empathy or solidarity are more the concepts we're looking for rather than identification'.

This emphasis on a connection across experience that is centred in feelings is also a feature of Surviving: Voices From Ravensbrück. In discussing the process of developing the exhibition, Kulturen Director Margareta Alin explained that the exhibition was designed as a 'study space' - a quiet space designed for viewing and reflecting upon a selection of objects from Kulturen's huge collection. But clearly, Surviving was designed as a study space of a very particular kind, one with a deliberate scenography intended to foster an affect-laden meeting with the traces of the experience of concentration camp survivors. The explicit curatorial intent was to present to visitors the 'voices' of the interned Ravensbrück women by displaying the material remains and transcriptions of verbal statements by survivors. These 'voices' were presented to viewers within a very specific mise-en-scene, a scenography that deliberately deemphasized the presentation of text. As Assistant Director Agneta Dahlberg explained:

the museum has chosen as a tactic... scenographic expression instead of text; that is a choice we have made in many of our exhibitions.... In many exhibitions we have had a dramaturge and a scenographer [who] add their competence to the knowledge of the museum staff. It's a way of developing the exhibition as a language, really.

Alin further commented on this:

Working with a scenographer allows you to address feelings. The scenographer is responsible for 'making the room;' he decides what colours to use. The [barracks] wall in the Ravensbrück exhibition, for example, was his idea. The dramaturge asks us what we are going to describe to the public; he works in the same way in the theatres. He is responsible for the ideas in the exhibition [the messages]. When we talk about the exhibition as a language, we mean putting objects in the kind of context that creates added meaning, or putting two or three objects in relation to each other to produce added meaning. It means there is no need for so much text.

Both exhibitions try to create these affect-laden 'meetings' that are clearly testamentary in character. However, the work of inheriting the bequest of this testament cannot be taken for granted. The crossing of boundaries of experience is rarely uncomplicated. Thus we need to consider not only the different ways in which such a meeting may occur, but when in such a 
meeting viewers might become part of an intimate encounter within which they revisit their own assumptions and alter in some way their own experience of the world. The meetings staged through the crossing of the boundaries of experience are often used as a justification for presenting 'difficult' exhibits. It is widely assumed that through such practices museums may inculcate a form of empathy in which one experiences a semblance of what someone else is thinking and feeling. Taken literally, this is tantamount to a projection of the self into the conditions of the other, a projection in which what is forgotten is the implication of oneself in one's response to another. As Freud remarked in Civilization and its Discontents:

we shall always tend to consider people's distress objectively - that is, to place ourselves, with our own wants and sensibilities, in theirconditions, and then to examine what occasions we should find in them for experiencing happiness or unhappiness. This method of looking at things which seems objective because it ignores the variations in subjective sensibility, is, of course, the most subjective possible, since it puts one's own mental states in the place of others, unknown though they be (1961: 41).

This is an important caution. Feelings are often offered as the royal road to promoting favorable understanding and solidarities across relations of difference. But as Freud suggests, we might complicate this assumption and consider the possibility that the feelings evoked are not just evidence of the capacity for empathetic resonance, but also symptomatic of the fears and needs established within one's own history, constituted as it is within structured relations of power, inequality, and subjection (Britzman 1998: 83-4). The point here is not to dismiss the importance of empathy, but to re-conceptualize it as a capacity for reaching out to another's experience in which our distinctive psycho-social history is maintained. Rather than presume a similarity of feelings, empathy thus reconceived becomes a relation of acknowledgement, a responsiveness to the feelings of others that opens the question of what it might mean to live in proximity to these feelings, to live in ways in which one experiences the force of these feelings to alter one's experience of the world and actions in it. This acknowledgement of the other's situation neither presupposes nor implies that one actually feels what the other feels. It is a process of being responsive to and reaching out toward another in which the other remains other, a process within which our distinctiveness as individual persons is not obliterated (Vetlesen 1994: 204-5).

In what ways, then, might Surviving and No Name Fever offer the possibilities of an intimate encounter? We are not suggesting that one exhibition encourages intimacy while the other discourages such an experience. It would be a mistake to simply propose that given the modest scale of Surviving and the diminutive personal objects within it, that this exhibition offers an intimate encounter whereas the massive No Name Fever, with its multiple simultaneous audio projections and moving images on large video screens, does not. Rather, our purpose is to consider how aspects of two very different exhibitions might be understood to encourage the possibilities of intimate encounters. In this way we intend to open up a conceptual discussion of how certain exhibition design features might help provoke such experiences. Intimacy is not solely a matter of physical scale leading to the narrowing of the interval between two points in space. If the hallmark of an intimate encounter resides in the notion of 'acknowledgement' as we have discussed above, what is it about exhibitions that might further this possibility? In thinking this question through, we have drawn on the observations made by Bonnell and Leroux as well as the personal reflections of Bonnell in regard to her encounters with various aspects of the exhibitions. Consequently, three design features common to both exhibitions seem to us as quite significant: (1) structures that enhance of the singularity of the experiences presented; (2) structures that enhance focus and absorption in specific objects and texts; and (3) structures that provoke a reflexive critique of one's grasp of what is being offered through the medium of the exhibition. We shall use these characteristics to present a detailed comparison of the exhibitions.

\section{Structures that enhance the singularity of experiences presented}

As a way of dwelling with the past, an intimate encounter offers the possibility of an altered way of living with and learning from images and stories that engage one's hopes and possibilities, 
limits and fears. As a sensibility with the capacity to unsettle the self, intimacy enables a reflexive critique leading to possible new insights regarding one's relationship to the past. But for intimacy to be sustainable, one's vulnerability must be combined with a responsible responsiveness, an answerability to the particularly of the traces of lives lived in incomparable circumstances. This requires an exhibition format that promotes an engagement with experiences whose specificity does not allow them to be collapsed into each other. Such a format may involve the use of artefacts, text, and audio/visual testimony to suggest not only the particularity of experience, but also the inadequacy of responses that subsume all traces presented as expressing the same story. Both exhibitions stage meetings with these particularities.

In No Name Fever, a diversity of experiences and viewpoints is immediately apparent: over one hundred quotations are included in the exhibit, from professionals, children, teenagers and artists from most parts of the world; within each polygon, multiple voices speak through text, video and audio media. The absence of curatorial commentary enhances the immediacy of this experience: visitors are invited to appreciate similarities and differences in experience without being 'guided' to draw particular connections or conclusions. While the exhibit does a priori frame the emotional range of response to HIVIAIDS infection by grouping instances representative of a particular theme (for example, Rage, Sorrow, or Fear), the range and diversity of individual statements across and within the seven polygons brings to the fore the specificity of these responses. A medical assistant from Tanzania describes the stigma attached to the disease: 'we go by foot or bicycle to see how our patients are. With the stigma it would be a problem if we went by car. People would know it was the AIDS car'. Reflecting upon her inability to afford treatment, twenty-five year old Vuyelwa Gucine of South Africa tells us 'I wish I had enough money to purchase my life'. Chath Piersath of Cambodia expresses his despair in a poem presented under the theme of 'Sorrow': 'this body is only temporary,/ a shell, a borrowed ship,

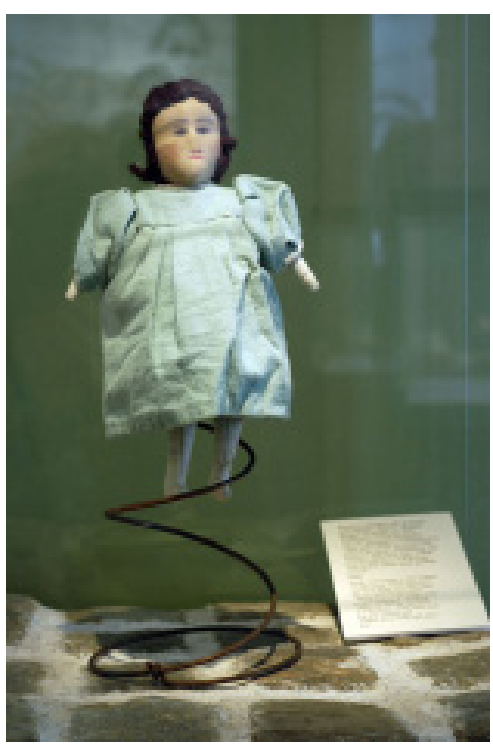

Fig. 5 A doll fashioned from scraps of smuggled cloth, used as a gift for children in the camp. Courtesy of Kulturen, 2005 a vessel/ leaving..../AIDS is now a war I face. I am losing,/afraid and lonely'. An executive of an American organization engaged in the fight against HIVIAIDS expresses hope: 'the AIDS epidemic will end, and when it does, it is important to know that some of us dared to care in the face of it, some of us dared to fight because of it, and some of us dared to love in spite of it'.

Divergent experiences are also evident in the exhibition Surviving. However, here various experiences are manifest through the material objects on display rather than in the proliferation of quotes from interviews with former inmates. While the objects are framed within thematic categories that threaten to reduce them to illustrations of these themes (for example, Sabotage, Practical Objects, Memorabilia), the material details of many of these objects break the confines of such categorization. This is so even at times when accompanying text attempts to pin down the representational significance of any given artefact. For example, in the cabinet titled 'Religion/Food for the Soul,' a collection of rosaries fashioned out of berries, grains and bread crumbs is accompanied by a quotation that reads: 'All prayer was strictly forbidden in the camp. If any German saw you praying, you got a terrible beating and were brought to the punishment block.....' While this quotation attempts to underwrite the meaning of the objects one sees, the objects themselves offer an incomplete gesture to the specific women who held and caressed these hand-crafted rosaries. What counting the 'beads' meant to any one of these women given what they were experiencing at the time we can never know. But what we do know is that these objects carry the presence and weight of individual suffering in a way that transcends their functional importance in a religious ritual. A similar example is the display of three miniature cloth dolls that lay in one of 
the drawers of the cabinet entitled 'Sabotage' (Fig. 5). The text accompanying these artifacts explains that dolls were used for smuggling messages between barracks and/or as presents for children. However, gazing at these objects such explanations hardly contain their significance. The material presence of these dolls in our time gestures back, indexically, to those moments of presence when a child in the camp held one of these objects. Again, what this action meant to that child is not something we might ever know, but what we do know is that these were treasures kept by the surviving inmates, post-war 'keepsakes' carrying the memory of the emotional weight of what they went through.

\section{Structures that enhance the focus and absorption in specific objects and texts}

In Kirshenblatt-Gimblett's discussion of another Swedish exhibition, Difficult Matters, she comments on the effect of exhibiting a small number of unique and remarkable objects in the space of a traveling museum trailer.

With so few and such singular objects... visitors are drawn into the space and towards each thing. Such compression encourages absorption, intense focus, attention to detail, and deep emotional resonance. One has the feeling of being inside a studio... or a private study, where one's thoughts and feelings are inspired by objects (Kirshenblatt-Gimblett 2000: 15).

What Kirshenblatt-Gimblett identifies here is her experience of heightened responsiveness to the traces of other lives. Clearly, she implicates the physical space in evoking this sensibility. In Surviving, the size and the intensely personal nature of the objects also encourage viewers to close out their surrounding social context in order to better attend to the particulars of the exhibition. Display cases present diminutive contents at eye level, obliging visitors to move quite close to the objects and enhancing their ability to view them from several angles. In this moment of drawing closer, time becomes less linear, less subject to the impulse to move through the exhibition. Rather the viewer is encouraged to dwell with the materials. It is as if this quiet, almost reverential space slows visitors down so as to begin to face the enormity of experience behind each object.

In contrast, in No Name Fever there are so many voices it is sometimes difficult to concentrate on any particular one. On the surface the potential for intimacy seems limited by the cacophony of perspectives and experiences that one meets. In a number of the polygons, the need to physically move close to the objects or installations is mitigated by the size of the screen and the volume of the video projection. It would seem that a sense of bombardment edges out the opportunity for reflection, creating a need for refuge in the face of the onslaught of images and text. And yet, despite this material organization of space, the heightened responsiveness discussed above is also evoked by this exhibition. Staff at the MWC reported that people slowed down and read, they sat and viewed video presentations on the small screens mounted within the display cases, and they talked to others about what they were encountering. ${ }^{10}$ These observations are drawn from interviews with Museum of World Culture front-of-house staff. Although statistics on visitor engagement and response were not available, museum staff had tabulated an average stay of 45 minutes for visitors to the No Name Fever exhibition.

And indeed it was the testamentary 'up close and personal' aspect of the exhibit in which a visitor might encounter many particular life narratives that presented possibilities for concentrated engagement and captivation. This is illustrated by the experience of Bonnell during her visit to the exhibition. ${ }^{11}$ After moving through the cacophony of sounds and images in the Anger polygon, Bonnell found that for her, the objects and documents categorized under 'Hope' created a more reflective, tranquil environment. On the far wall of the space, women from the Bambanani Women's Group in South Africa reflected on their experience with HIVIAIDS, and their hopes for the future, in a series of life-size 'body maps'-outlines of their bodies filled in with colourful depictions of the effects of the virus on their lives (Fig. 6). Each of the women had received anti-retroviral drugs through a project sponsored by Médecins Sans Frontières, and each had new reasons to imagine a future. Nondumiso, one of the women, sketched the following words alongside the image of her body: 
I've won the battle, it's been a long battle. I've disappointed the devil. The ARVs have helped a lot but this skin is taking time to get better. By the second month I was well. It's amazing. On my picture I drew the virus - it's a small blue dot. The white is my blood. The red circles are the ARVs eating the virus, and the virus is going down. The ARVs are strong.

The body maps were engrossing and intensely personal, and Bonnell found herself tracing their pathways of fluid and cells, attentive to the differences in scale that suggested the strength of the ARVs combating the smaller, shrinking virus cells. Nondumiso had placed an imprint of her hands over the sketched outline of her hands in the image; her fingerprints were almost visible in the impress of the paint. As Bonnell said of her experience, 'I felt as though she was present for a moment, with all the complexity and unknowability of her long battle with AIDS, and with all the elation and awe of her recovery. For those moments with Nondumiso's body map I felt alone with her story; the rest of the room and the rest of the exhibition were momentarily removed from my attention'.

\section{Structures that provoke a reflexive critique of one's grasp of the exhibition}

Recall that an intimate encounter suggests a relation in which one inhabits the world but does not settle it. This implies a vulnerability to the force of events that come to one from outside the self, a force that is unable to

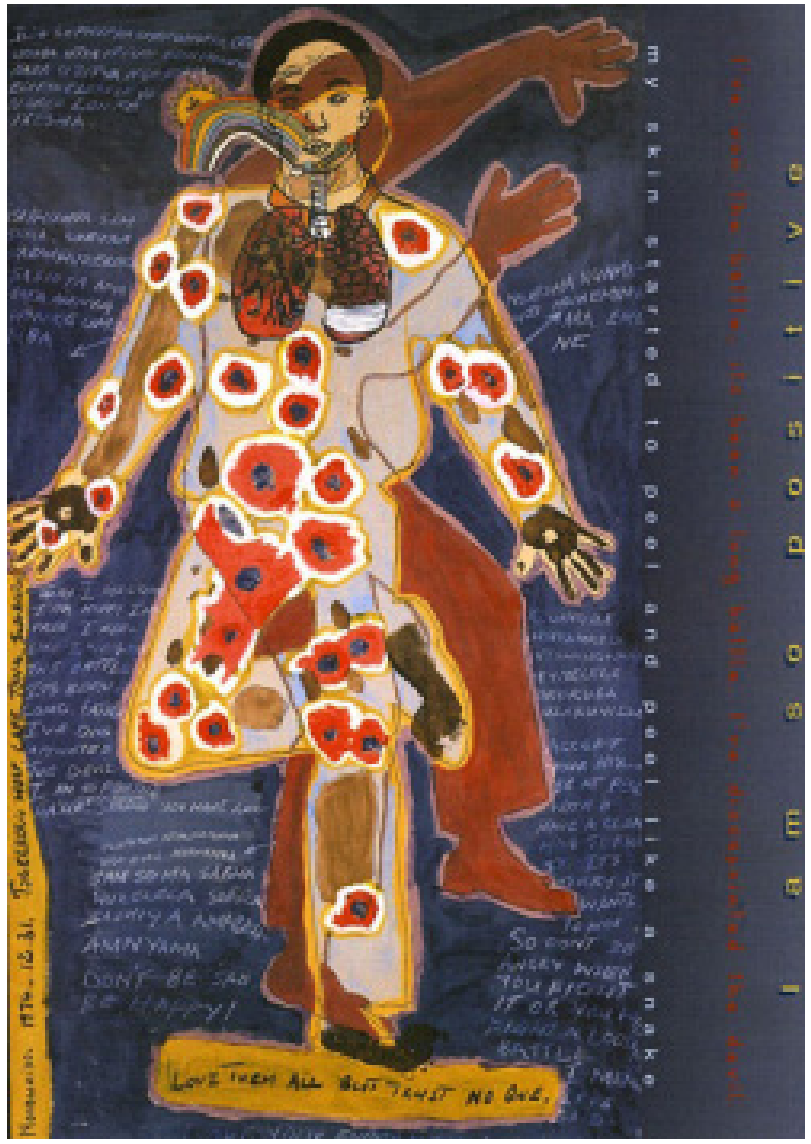

Fig. 6 Body map by Nondumiso, a member of the Bambanani women's group in South Africa. Purchased forthe collection of the Museum of World Culture, Sweden. Courtesy of the Museum of World Culture, 2005.

be contained by the confidence in and certainty of one's concepts and desires. Intimacy in the exhibit hall then references a moment when one becomes undone, absorbed in the singularity of another's existence. It is that moment in which words fail and meaning is unresolved, yet one still faces an unabated demand to acknowledge the life which one now encounters.

As we discussed earlier, despite the objects presented in Surviving being grouped for display based on their significance or function, it is the specificity and detail of certain objects within the mise en scène of the exhibition that invite viewers into a space where intimacy is possible. For Bonnell, this sense of intimacy emerged in encountering a red handkerchief embroidered with lace within one of the drawers of the 'Treasures and Gifts' cabinet. Next to the object, a quotation from a survivor named Maria read: 'We gave each other presents on birthdays, often a drawing but also tiny little things we had embroidered or sewn'. Curatorial text provided additional context: 'in the chaos of the camp, gifts were important links between the 
prisoners. They tried to give presents on special days and when they wanted to honour someone'. Yet, attending to the handkerchief's particularities-its delicacy, colour, and exquisite craftsmanship-Bonnell found herself struggling to be answerable to the woman who treasured it. 'Did it remind this woman of something she used to own, or that her mother or sister used to own? Did its style of craftsmanship remind her of similar articles from home? Or, was the handkerchief simply a bright piece of fabric, an other-worldly luxury so incongruous with her present surroundings that it helped to carry her imagination to another place?' In contemplating the red handkerchief, Bonnell came face to face with the question of how to take in and care for the object as a memorial trace. Her questions reflect in part the process of encountering traces of another's life, of acknowledging the force of such an encounter without attempting to define or 'know' the other's experience, and without losing one's own sense of distinctness in the process. Crucially, she is also brought to the point of wondering: 'What insight might I make from these questions? How might I come to terms with my own remembrance of traces offered by the exhibition? How are these questions related to my struggle to live with this history?'

No Name Fever is no less a site of intimate encounters, but here the encounter takes a different form of unsettlement. As indicated above, in this exhibition, curators placed images, texts, and objects in non-hierarchical juxtaposition in a deliberate attempt to destabilize the meanings associated with particular objects or texts. Although some degree of hierarchy is present in the placement of materials into broad categories of emotion, the relationship between objects and texts within the individual polygons is less logically defined. This meant there was little structure in No Name Fever to contain the overwhelming presentation of tragedy and trauma that is offered as the AIDS crisis. Emotion is the language of this exhibition and it is this surplus of emotion, exceeding the meaning of any given text or image, which is so unsettling, which literally undoes the visitor. If one doesn't escape this discomfort by simply fleeing the exhibit, it is possible to find oneself being drawn into an uncanny encounter with the lives traced through particular texts or video presentations. The presence and singularity of death in this exhibition poses difficult questions with no easy answers.

For Bonnell, this overflow of emotion occurred near the end of her tour of the exhibition, standing before Gideon Mendel's photograph of the 'Coffin with Red Ribbons' in the Sorrow polygon. This image, if you recall, shows the coffin of fifteen-year-old Khanyisa Eugenia being lowered into her grave, covered at her request not with flowers but with tiny red AIDS ribbons. Accompanying text charts the rising number of funerals in South Africa, and the effects of such unprecedented death rates upon mourners and gravediggers in small communities. 'Nearly everyday there is a funeral for someone we know,' an adjacent quotation comments; 'sometimes there can be more than six funerals happening at the same time.' With the weight of the exhibition behind her, and the bombardment of multiple voices, multiple losses, multiple grief, Bonnell surrendered herself to the loss of this one fifteen-year old girl:

I felt overwhelmed by anger and sadness, by a sense of grief that was for a moment my grief. At the same time I felt the distance of viewing this moment in time that was past now, the glass panel over the image reminding me of the giant chasm that separated her experience from mine, standing in the comfort of a museum exhibition in Sweden. I wrestled then, as I do now, with how to come to grips with the enormity of loss in this community, and with Khanyisa's courage in covering herself, even in death, with symbols of the fight against AIDS in a country where the disease is so stigmatized. Like the red handkerchief in the Ravensbrück exhibition, the image of Khanyisa's coffin has stayed with me. In thinking about her today I feel like l am nurturing the memory of my encounter with her, or traces of her, and by doing so I am trying to come to grips with my role, and my responsibilities, as a witness.

\section{Conclusion}

The purpose of this paper has been to open up some questions about the way that 'difficult' exhibitions can take on a force in our lives. As practices of public history, such exhibitions not only expand the traces of the past it is possible to encounter in museums, but also set the terms 
on which they are to be engaged by visitors. It is precisely these terms that deserve a great deal more attention in museology. It is in this regard that we have here explored the implications of exhibition structures that make possible the experience of intimacy. In this context, the significance of intimacy lies in its nature as affective experience carrying quite consequential ethical and political considerations. There is much to be learned not only about 'difficult' histories but from them. Exhibitions that grapple with 'the dark side' of human existence must function as more than 'post-it' notes reminding us of our commitment to prevent such histories from being repeated. Nor should they be justified only in terms of offering experiences that might stimulate feelings comparable to those held by others, assuming that this will encourage efforts to relieve existing pain and suffering while preventing their re-occurrence. Exhibitions that offer the possibility of intimacy solicit visitors into a 'difficult' engagement with the experiences of others that radically calls into question the adequacy of one's concepts to tie down the significance of lessons of the past. When this occurs, a transformative moment of learning is possible. On such terms, exhibitions can offer the possibility of a museum practice that, rather than responding to the question of what we must remember in order to be, challenges us to ask what it means, in light of the experience of the past, to be what we are now (and, perhaps more significantly, how we might be in the future). For such a practice to be realized, public history must be capable of animating a critical historical consciousness - a way of living with and within history as a never-ending question that constantly probes the adequacy of the ethical character and social arrangements of daily life.

Received 20 ${ }^{\text {th }}$ December 2006 Finally accepted $18^{\text {th }}$ May 2007

\section{Notes}

1 A portion of the research and writing of this article was funded by the Social Sciences and Humanities Research Council (Canada). We would like to thank the staff at Kulturen and at the Museum of World Culture for generously providing their time and assistance, particularly Jette Sandahl and Christine Palmgren at the MWC, and Agneta Dahlberg, Margareta Alin, and Anita Marcus at Kulturen. Thanks to Darryl Leroux and Clare-Estelle Daitch for their vital research support in the early stages of the project, and to Deborah Britzman and Mark Clamen for their comments on an earlier draft of this paper. Special thanks to Eva Silvén of Nordiska Museum in Stockholm for connecting us with various museum professionals in Sweden working with difficult subject matter, and for making our stay in Sweden such a productive and enjoyable one.

2 The typical justifications for presenting exhibitions that focus on violence, suffering and loss is that they inform, remember, and encourage reflection on one's moral and spiritual commitments. In this regard, there is a considerable critical literature intended to interrogate these justifications as they apply to specific Holocaust museums and exhibitions. For excellent examples of such work see Ellsworth (2002) and Edkins (2003). While such considerations have been extended to exhibitions addressing other instances of aggression in human relationships (eg Newbury 2005), few of these studies consider why and on what terms the presentation of such material in museums might be understood as engaging visitors with the problems of difficult knowledge. Perhaps the most sustained consideration of such issues among those working in museum studies has taken place in Sweden. For an excellent overview of this work see Silvén and Björklund (2006). For an earlier report on such concerns in Sweden see Kirshenblatt-Gimblett (2000).

3 At the Museum of World Culture, we interviewed the Museum Director; the Curator of the No Name Fever exhibition; directors of the Communications, Education, and Programs departments; and two Front of House staff. At Kulturen, we interviewed the Museum Director, her Executive Assistant, and the Curator of the Surviving exhibition.

4 Neither museum could provide visitor statistics for these exhibitions in isolation. Visitor responses for the No Name Fever exhibition were confined to a wall at the centre of the 
exhibition space where visitors could post comments on 'sticky notes'. A comment book was available for the Surviving exhibition, together with written commentaries from school groups; these materials might prove fruitful for subsequent research.

5 See, for example: Dubin (2001), Kohn (1995), Levitt (2005), and Linenthal and Engelhardt (1996).

6 One of central problems of any exhibition of 'difficult material' is to offer structures through which the work of inheritance is not foreclosed by moralism or ideology. It is worth underscoring that any re-presentation of the past can itself become a commodity, reified in institutions and subject to the hunger for images and narratives that can be manipulated in the interest of the powerful affects these both serve and generate. See Wyschogrod (1998).

7 The vulnerability and apprehension experienced in such an encounter may also derive from transference, where the affective force of the current experience may be intensified by unresolved psychic conflicts in one's own past.

8 The interviews were archived in the university library in Lund, where, throughout the remainder of the century, they were inaccessible both to the general public and to other institutions such as Kulturen. Not until the early 2000s were the restrictions removed from these interviews. As of early 2006, twenty-five of these interviews have been translated into English and are accessible on the Library website. While the interviews provided important background context for the 2005 exhibition, they do not discuss the objects specifically.

9 In the exhibition, these themes are expressed in Swedish. English translation of thematic categories was provided by Kulturen curatorial staff.

10 These observations are drawn from interviews with Museum of World Culture front-of-house staff. Although statistics on visitor engagement and response were not available, museum staff had tabulated an average stay of 45 minutes for visitors to the No Name Fever exhibition.

11 It is important to note here that we have included Bonnell's observations not to suggest that her experience is somehow representative of all visitors (each of whom would have their own necessarily personal responses to the exhibition), but rather to serve as an example of what aspects of an intimate encounter might include. The value of these observations lies not in assessing the success of the exhibition in staging intimate encounters, but rather the fruitfulness of exploring the notion of intimacy within the context of difficult exhibitions.

12 For a detailed discussion of public history on these terms see Létourneau (2004).

\section{References}

Britzman, D. P. (2000) 'If the Story Cannot End: Deferred Action, Ambivalence, and Difficult Knowledge,' in Roger Simon, Sharon Rosenberg, and Claudia Eppert (eds) Between Hope and Despair: Pedagogy and the Remembrance of Historical Trauma, 27-58, New York: Rowman and Littlefield.

Britzman, D. P. (1998) Lost Subjects, Contested Objects: Toward a Psychoanalytic Inquiry of Learning, Albany: State University of New York Press.

Bruns, G. (1999) Tragic Thoughts at the End of Philosophy: Language, Literature and Ethical Theory, Evanston, IL: Northwestern University Press.

Dubin, S. C. (2001) Displays of Power: Memory and Amnesia in the American Museum from the Enola Gay to Sensation, New York: NYU Press. 
Derrida, J. (1994) Specters of Marx: The State of the Debt, the Work of Mourning, and the New International, New York: Routledge.

Edkins, J. (2003) 'Concentration Camp Memorials and Museums: Dachau and the U.S. Holocaust Memorial Museum' in Trauma and the Memory of Politics, Cambridge: Cambridge University Press, 111-174.

Ellsworth, E. A. (2002) 'The U.S. Holocaust Museum as a Scene of Pedagogical Address,' Symploke 10 (1-2) 13-31.

ICOM. (1991) 'The Language of Exhibitions,' Vino Sofka, ed, ICOFOM Study Series 19, Stockholm: ICOFOM.

Kirshenblatt-Gimblett, B. (2000) 'The Museum as Catalyst,' Keynote Address, Museums 2000: Confirmation or Challenge, ICOM Sweden, the Swedish Museum Association and Swedish Travelling Exhibitions/Riksutställningar, 29 September 2000, Vadstena, Sweden.

Kohn, R. H. (1995) 'History and the Culture Wars: The Case of the Smithsonian Institution's Enola Gay Exhibition,' Journal of American History, 82 (3) 1036-63. Kulturen Cultural History Museum. 2006, Brochure. Lund, Sweden: Kulturen. http://www.kulturen.com/

Létourneau, J. (2004) History for the Future: Writing Memory and Identity in Quebec, Montreal and Kingston: McGill-Queen's University Press.

Lévinas, E. (1991) Otherwise than Being: or, Beyond essence, Dordrecht, Netherlands: Kluwer Academic Publishers.

Levitt, Laura S. (2005) 'Refracted Visions: A Critique of "Mirroring Evil: Nazi Imagery/Recent Art,"' Studies in Gender and Sexuality, 6 (2) 199-216.

Linenthal, E. T. and T. Engelhardt (eds). (1996) History Wars: the Enola Gay and other battles for the American past, New York: Henry Holt.

Mauss, M. (1954) The Gift: Forms and Functions of Exchange in Archaic Societies, Trans. Ian Cunnison, London: Cohen and West.

Museum of World Culture (2004) press release, 16 ${ }^{\text {th }}$ December, 'December 29th, 2004 marks the opening of the new Museum of World Culture in Sweden.'

Newbury, D. (2005) "Lest we forget:" Photography and the Presentation of History at the Apartheid Museum, Gold Reef City, and the Hector Pieterson Museum, Soweto', Visual Communication, 4 (3) 259-295.

Pearce, Susan M. 1992, Museums, Objects and Collections: A Cultural Study, Leicester: Leicester University Press.

Pearce, S. M. (1994) 'Objects as Meaning; or Narrating the Past,' in Interpreting Objects and Collections, 19-29, New York: Routledge.

Pitt, A. and D. Britzman. (2003) 'Speculations on Qualities of Difficult Knowledge in Teaching and Learning: an Experiment in Psychoanalytic Research', Qualitative Studies in Education, 16 (6) $755-76$. 
Silvén, E. and B. Andres. (2006) 'Detecting Difficulty' (English introduction), in Svåra Saker: Ting och Berättler som Upprör och Berör (Difficult Matters: Objects and Narratives that Disturb and Affect), Stockholm: Nordiska Museet.

Simon, R. I. (2006a) 'The Terrible Gift: Museums and the Possibility of Hope Without Consolation,' Journal of Museum Management and Curatorship, 21 (3) 187-204.

Simon, R. I. (2006b) 'Museums, Civic Life, and the Educative Force of Remembrance,' The Journal of Museum Education, 31 (2) 113-22.

Tate, D. L. (2003) 'Tragic Thoughts at the End of Philosophy: A Review of Gerald Bruns, 1999, Tragic Thoughts at the End of Philosophy: Language, Literature and Ethical Theory.' Evanston, IL: Northwestern University Press. Journal for Cultural and Religious Theory, 5 (1) 155-9.

Vetlesen, A. J. (1994) Perception, Empathy, and Moral Judgment: An Inquiry into the Preconditions of Moral Performance, University Park, PA: The Pennsylvania University Press.

Wineburg, S. (2001) Historical Thinking and Other Unnatural Acts: Charting the Future of Teaching the Past: Critical Perspectives on the Past, Philadelphia:

Temple University Press.

Wojnarowicz, D. (1991) Close to the Knives: A Memoir of Disintegration, New York: Vintage Books.

Wyschogrod, E. (1998) An Ethics of Remembering: History, Hetereology, and the Nameless Others, Chicago: University of Chicago Press.

*Jennifer Bonnell is a doctoral student in the History Education Program at the University of Toronto's Ontario Institute for Studies in Education. A research associate for the Legacy of Testament project at the University of Toronto's Centre for Media and Culture in Education, Bonnell has conducted research on 'difficult' museum exhibitions around the world. She is the former curator of the Multicultural History Society of Ontario's award-winning Oral History Museum, and has over 10 years experience conducting oral history research and coordinating community history projects for the museums sector in British Columbia and Ontario, Canada.

\section{Address}

Department of Theory and Policy Studies

Ontario Institute for Studies in Education

University of Toronto

252 Bloor St. West, $6^{\text {th }}$ Floor

Toronto, Ontario M5S 1V6 Canada

Email: jbonnell@oise.utoronto.ca

Phone: 14165342221

Fax: 14169264741

** Roger I. Simon is Professor of Culture, Communications and Critical Education in the Department of Sociology and Equity Studies, Ontario Institute for Education at the University of Toronto. Simon is also Director of the University of Toronto's Centre for Media and Culture in Education. He has published widely on questions of history memory and practices of remembrance. His latest book is The Touch of the Past: Remembrance, Learning, and Ethics published by Palgrave MacMillan in 2005. 


\section{Address}

Department of Sociology and Equity Studies

Ontario Institute for Studies in Education

University of Toronto

252 Bloor St. West, $12^{\text {th }}$ Floor

Toronto, Ontario M5S 1V6 Canada

Email: rsimon@oise.utoronto.ca

Phone: 14169236641 ext.2425

Fax: 14169264751 